\title{
Empathy as core to the development of holding and recognition: the case of Garret
}

\author{
Zelda Gillian Knight \\ University of Johannesburg, South Africa
}

\begin{abstract}
Heinz Kohut investigated empathy in psychoanalysis in the mid-1950s and found it to be a powerful way to connect to, and be with, his patients. Since then, relatively few recent clinical cases of empathy have emerged, while theoretical discussion of empathy seems to be the norm. Moreover, empathy has not been linked to the development of holding and recognition. The Winnicottian notion of the holding metaphor, which describes the mother holding her infant, has been controversial but continues to be used in therapy. Revised by relational theorists, holding is now viewed as co-created within the intersubjective space. Few recent clinical cases exist showing how and what holding looks like in therapy. The concept of recognition, also used in therapy, is defined as the ability to recognize and experience the other as a separate other. Clinical cases showing recognition in therapy are few in number. As far as I know, no clinical cases suggest that empathy is necessary before holding and recognition can emerge. In this paper, identifying these clinical case gaps in the literature, I describe a small verbatim section of a session with my patient, Garret, in which I attempt to; i) show the empathic process, thus adding to the scarcity of clinical cases, and, ii) show the experience of holding and recognition as they emerge in this case, and iii) suggest that empathy is a necessary core process to the development of the experience of holding and recognition.
\end{abstract}

Key words: Empathy; holding; recognition; clinical; relational.

\section{Introduction}

Within psychoanalytic and relational psychotherapy, empathy, as a concept that describes a way of being with our patients, is defined as the act of feeling oneself and thinking oneself into the inner life of another, to know, both emotionally and cognitively, what the other thinks and feels (Ornstein, 2011). As a concept, it has endured since Heinz Kohut in the mid-1950s first suggested it's

Correspondence: Zelda Gillian Knight, Department of Psychology, University of Johannesburg, South Africa.

E-mail: zknight@uj.ac.za

Citation: Knight, Z. G. (2020). Empathy as core to the development of holding and recognition: The case of Garret. Research in Psychotherapy: Psychopathology, Process and Outcome, 23(2), 180188. doi: $10.4081 /$ ripppo. 2020.457

Conflict of interest: the authors declare no potential conflict of interest.

Received for publication: 16 March 2020.

Revision received: 13 June 2020.

This work is licensed under a Creative Commons Attribution NonCommercial 4.0 License (CC BY-NC 4.0).

${ }^{\circ}$ Copyright: the Author(s), 2020

Licensee PAGEPress, Italy

Research in Psychotherapy:

Psychopathology, Process and Outcome 2020; 23:180-188

doi:10.4081/ripppo.2020.457 curative potential and as a way of being with patients. It is more recently been suggested that empathy not only permits a prolonged, sustained entry into the inner world of the patient, it also designates the boundaries of the therapeutic relationship in the sense that only what is accessible via empathy can be called psychotherapy (Ornstein, 2011). As an enduring concept, however, recent clinical cases of empathy, thus showing what empathy looks like in the process, are few in number (Bacal, 1990; Fosshage, 1997; Grant \& Harari, 2011; Geist, 2013; Ornstein, 2011; Pillsbury, 2019; Slavin \& Kriegman, 2009; Stolorow, Atwood, \& Orange, 2002).

The equally enduring concept of holding has been in existence since the mid-1950s, (for example, Winnicott, 1955). The holding metaphor, which describes the mother holding her infant, first established by Donald Winnicott, has been adopted within the therapeutic community to describe the paralleled relationship between maternal care of her infant and the analyst-patient relationship. In this context, the Winnicottian mother/analyst sheltered the vulnerable baby/patient from toxic environmental impingements in an effort to allow the patient to contact early failures, and to thus support access to previously hidden true self experience (Slochower, 2011; Winnicott, 1955). It was assumed, therefore, if the analyst were to be the symbolic mother, the possibility of reworking early trauma was understood as possible; what cannot be remembered can be re-experienced in the holding position, and then repaired (Slochower (2011). The implication being that the patient can, in fact, be an infant again, but with a better, more responsive mother-analyst (Slochower (2011). 
There were some conceptual problems with this metaphor of holding as pointed out by relational theorists and feminists, but it has endured into contemporary times because it has been revised within the light of both social constructivist theory and the relational turn in psychoanalytic psychotherapy (Atlas \& Aron, 2018; Aron, 1996, Mitchell, 2000). As a result, usage appears to be maintained because it now has a relational perspective. It remains, however, to be approached largely from the theoretical level, rather than at the more practical, and experience near, clinical level, rendering it to be abstract and difficult to know what it looks like when it emerges in therapy. There are, it is recognized, some recent and useful clinical case studies using holding (Bion, 1962; Bollas, 1978; Slochower, 1996; 2011; 2014) but they appear to be few in number, and not rooted in the idea that empathy first needs to be present and exist before the experience of holding can exist.

The concept of recognition is not new to psychoanalytic psychotherapy. Recognition is defined as the capacity to psychologically recognize, see, know, and experience the other as a separate other (Benjamin, 1988, 2018). Clinical cases of recognition as it appears, exist primarily in the work of Jessica Benjamin, but she does not put forward the idea that empathy first needs to be established before recognition can exist.

Moreover, most of the clinical cases that discuss these three concepts do so in isolation to each other, or when they do, they are not linked to the notion that empathy is core to the development of holding and recognition. In other words, I have been unable to find recent clinical cases where all three concepts are shown to emerge in sessions, and where there is the idea put forward that it is empathy that facilitates the emergence of holding and recognition.

\section{What this paper is about}

Since the mid-1950s, empathy has been recognized as important to the therapeutic process. Given the scarcity of recent clinical cases showing what empathy looks like, as well as what holding and recognition may be if they appear in a session, and their relationship to empathy, in this paper I set out to describe a section of a session with my patient in which I attempt to; i) show the empathic process, thus adding to the dearth of recent clinical cases, and, ii) show the occurrence of the experience of holding and recognition as they emerge in this same case with my patient, and iii) suggest that empathy is a necessary core experience to the emergence of holding and recognition.

I work within a relational psychoanalytic framework, with the idea that there are two subjectivities in the consulting room (Benjamin, 1988, 1995, 2018), thus two minds each co-contributing to the therapeutic process. The implication of this relational perspective is that the subjectivity of the analyst plays a role in how the process unfolds as much as the subjectivity of the patient is implicated in the same unfolding. It is for this reason that I give an account of my experience with Garret.

\section{The empathic process}

Heinz Kohut $(1959,1981,1984)$ who undoubtedly pioneered our understanding of the role of empathy in therapy, placed it at the heart of the analytic process. He viewed empathy as potentially curative and thought of it as a way to be with patients that made them feel deeply understood. He, however, struggled for many years with both the manifold meanings of empathy and his indecisive attitude toward its potentially curative effect (Geist, 2013). Just a few days before he died, he made a statement about empathy that put it into the center of the analytic process. He said, “. . . despite all I have said, empathy, per $s e$, is a therapeutic action in the broadest sense, a beneficial action in the broadest sense of the word" (1981, p. 530). While Kohut offered various meanings of empathy such as a definer of the field (the methodology for collecting our data), as an informer of our therapeutic actions (how we respond to the patient), and as a facilitator of empathic resonance (opening up mutual pathways of empathy between patient and analyst), he baulked in presenting the myriad ways that empathy contributes to the healing process (Geist, 2013).

Since Kohut's conceptualization of empathy, which appears to be based more on a one-person psychology, i.e., it is what the therapist does, relational analysts have re-formatted empathy as emerging between the two people in the session, and thus as an experience of mutuality, and arising from the psycho-dynamics of the intersubjective space. The work of Sarah Pillsbury (2019), Ornstein (2011), Slavin and Kriegman (2009), Fosshage (1997), Stolorow, Atwood, and Orange (2002), and Richard Geist $(2007 ; 2010 ; 2013)$ to name but a few, have been innovators in re-shaping empathy as relational and bi-directional. These relational writers have shown that empathy, as a mutual process, does not just belong to the person of the analyst. This shift to the intersubjective space means that empathy for some is core to the therapeutic process in that it determines the depth and healing potential of any treatment (Geist, 2013). Empathy, in this regard, permits analysts a potentially experience-near consideration of how the unconscious emerges from empathic interchanges (Stolorow et al., 2002).

While both relational and contemporary self-psychologists continue to dispute whether and how empathy may contribute to the healing process (Geist, 2013), empathy is often theorized rather than presented in a clinical case that applies it to the dialogue between patient and analyst. Given this gap, some authors such as Geist (2013) and Ornstein (2011), have begun to describe sessions in which empathy is a major part of the process, thus showing how it emerges, and its curative potential. Moreover, it has been noted that rarely are the experience-near clinical questions of how the therapist or analyst actually enters 
another's subjective world, are discussed, and thus, how the patient permits the analyst into her own world, and how empathy impacts intersubjective healing processes in any given therapeutic session (Geist, 2013).

For the purposes of this paper, I am staying close to the ideas and definition of empathy as described by Geist (2013). To paraphrase Geist, empathy is defined not so much as a listening stance (Fosshage, 1997) or a methodology for collecting data (Kohut, 1959); although clearly it is both, but as a continual and mutual process that occurs between patient and therapist. Geist asserts that the empathic process unfolds when we imaginatively feel and think our way into another's life, experience his or her inner world from the patient's point of view, and convey our understanding of what we experience back to the patient in a way that encourages the patient to correct, elaborate, or clarify, our understanding.

In this context, empathy is a mutual and bi-directional process within the intersubjective space that is shared. On the one hand, notes Geist, it is a reaching out to understand our patient's inner world, and a sharing of that understanding with the patient. On the other hand, it is an active invitation to the patient to empathically search out the therapist's subjectivity, theory, and style of relating, for without knowing and experiencing the therapist's subjectivity, the patient cannot begin to trust or know what affective states the therapist can manage, tolerate, survive, and welcome (Geist, 2013). In other words, the empathic process determines the content and process as well as emotional connections that will emerge in the intersubjective space of both the patient and the therapist (Geist, 2013).

In summary, the empathic process allows for the patient to feel deeply understood, which means that the patient knows we know about what is happening to him or her, and can survive this knowing in service of the patient's self-development and self-exploration - perhaps their engagement with their true self (Winnicott, 1955).

\section{The holding metaphor in the therapeutic process}

One of the most well-known metaphors developed by Donald Winnicott $(1955 ; 1960)$ is that of holding. It describes the mother as protecting her vulnerable baby by holding him in her arms. As she physically holds her child, she takes care of not only the physical needs but also the psychological aspects of her child. In the safety and strength of her arms, the child's psyche begins to take shape and form. The metaphor of holding and a holding environment has been a part of psychoanalytic therapy for many decades, and it also included the father as part of the "holding environment" (Winnicott, 1960). Transferred into therapy, this metaphor of a mother holding her child became paralleled with the way the analyst potentially holds her vulnerable patients.

Holding was thus conceptualized as a safe place created by the analyst for the patient in which the patient could rest and melt into the psychic presence of the caring mother/analyst, and be permitted to let go of reality and regress to earlier states of developmental arrest in service of reparation and healing (Winnicott, 1960).

In this context, Winnicott (1960) viewed holding as including the analyst's necessary provision of insulation from impingements from the external world. This insulation was important for it facilitated a process whereby patients could experience their interiority without interruption. This almost cocooning position permitted psychic development to occur and experiences of ever-increasing integration and personalization.

But ideas like regression to dependence and the analyst's holding function collided with social constructivist theory and feminist critiques of the idealization of motherhood (see, e.g., Chodorow, 1978; Benjamin, 1988; Bassin, Honey and Kaplan, 1994). Mitchell (2000), Aron (1991; 1992), Hoffman (1991), Stern (1992), Tansey (1992), Burke (1992), and others challenged the supposition that it's possible for the analyst to function within a holding frame (Slochower, 2011). Critiquing holding's developmental tilt, they emphasized the patient's adult status and the impossibility of replicating the maternal environment in the analytic setting (Slochower, 2011).

In addition, relational analysts such as Slochower (1996; 2011; 2014) and Aron (1991, 1992) noted that there were a few other flaws with this metaphor for it seemed to them that Winnicott neglected the essentially relational, intersubjective space of holding in terms of what goes on between analyst and patient. Furthermore, Slochower (2011) deconstructed what she saw as an idealized version of the mother-infant bond, mirrored in the work of Chodorow (1978) and Benjamin (1988), and too closely linked with the patient-analyst relationship, thus infantilizing the patient. In the holding position, she is especially critical of Winnicott's view of the largely passive and sacrificing mother, and sees this mother's subjectivity as almost vanishing. "Neither mothers nor analysts are capable of anything close to perfect affective responsiveness; the analyst cannot empty herself of herself, and it is mystifying and countertherapeutic to pretend otherwise (Slochower, 2011, p.502).

Other relational theorists, such as Bion (1962), Loewald (1960), Balint (1968), Bollas (1978), and Slochower $(1996,2006,2011,2014)$ have, since then, contributed to the concept of holding as relational and thus as occurring within the intersubjective space. Arguably, the principle relational theoretical trailblazer in the forging of a new, post-Winnicott vision of holding is Joyce Slochower (1996; 2006; 2011; 2014).

Slochower (2011) who did not abandon the metaphor, claims that a collision occurred between two conceptions of the analytic space. The one organized around visions of a maternal Winnicottian holding environment, and the other grounded in the actuality of the analyst's separate subjectivity and the fruitfulness of intersubjective exchange. She asserted, however, that sometimes the otherness of the an- 
alyst's subjectivity is not always helpful, especially for more vulnerable patients or those less able to sustain interiority experiences. Healthier patients can work with and in the subjective space. For these healthier patients, she worked with the metaphor of holding. She maintained that when working with these healthier patients, and within a modified approach to holding, holding helped establish a containing and affectively resonant space, "a thicker buffer against evidence of my separateness that limited derailment and facilitated self-exploration" (p. 502).

I argued for the importance of holding as one analytic thread while reformulating its dynamics and introducing the idea of analytic bracketing. Holding does not require holding back, i.e., deleting one's reactions as relational critiques (e.g., Bass, 1996) suggested; the holding analyst struggles to bracket - that is, to sustain contact with her subjectivity without actively introducing it into the therapeutic dialogue. The purpose of this bracketing process is to create a (partially) protected space within which to access and articulate her experience (p.502).

By introducing the concept of bracketing, she effectively attempted to bridge two positions: One that emphasized the analyst's irreducible subjectivity; and the other, the patient's need not to know what the analyst thinks or feels about her (or anything else). The concept of bracketing embodied the there-but-not-there quality of analytic subjectivity within a holding frame and makes room for leakage, i.e., ways in which the holding analyst unavoidably fall short or fails to hold (Slochower, 2011).

Staying close to her ideas in this paper, it is also important to show that she therefore used the holding metaphor to show how it is not about regression to dependence, but how it might function in work with patients expressing intense affect states, such as hate, envy, and self-involvement (narcissism). In this situation, she indicated that for her holding means abstaining, as much as possible, from expressing one's disjunctive subjectivity while attempting to remain within the patient's experiential sphere. The implication is that she viewed that the analyst within this holding metaphor, in the attempts to hold hate, envy, dependency, or other affect states, as establishing a "temporary illusion of analytic attunement" (p.502) within which the patient's experience of the analyst remains unchallenged. She notes that it is possible that the analyst will represent a good mother, but the holding illusion sometimes coalesces around the patient's experience of the analyst as this non-retaliatory figure. In this line of thought, she remarks that it's also worth noting that, although the patient in a holding frame may feel deeply understood, the illusion of attunement can also be "experienced as absence" (of threat, of the other) or as aliveness (p. 502).
Holding is not everything and thus core to the analytic process. It is one kind of experiencing for the patient. It is an experience that can be returned to, and then, moved away from into more intersubjective engagement. It is not for all patients. Some patients will not tolerate anything introduced by the analyst.

What does this holding experience look like then? For Slochower $(2006 ; 2011 ; 2014)$ she thus pays attention to her patient's reactions to her otherness, and asks if the patient can sustain access to his experience of self and other while also recognizing and responding to difference? Or does the patient negate one of these, for example, dismissing or ignoring her input, or abandoning his own perspective on himself?

In summary, there are moments of working intersubjectivity and moments when there is holding. Because our subjectivity cannot be left outside the consulting door, it means that we / the analyst does not hold alone; holding is a co-constructed phenomenon in which the patient participates. But holding means that we bracket something of ourselves, and thus our subjectivity is less / lessened. It means that our patients can ignore our otherness / separateness. Thus, holding is a particular type of experiencing, it allows for the patient to not know us, or for our otherness to not be so visible to them. It is also important to move away from holding and our bracketing to intersubjective experience (and tolerance of their separateness and our separateness) where our otherness is seen and experienced by our patients, (which is not holding) and thus a part of the process. In other words, there is a developmental trajectory inherent in the move from holding toward collaboration (Slochower, 2006; 2011; 2014). This trajectory is not in one direction but can be circular, and thus holding can be an experience that is returned to depending on the patient's process, needs, capacities and necessities.

\section{Recognition in the process of therapeutic engagement}

Jessica Benjamin $(1988,1995,2018)$ is perhaps best known for her contributions to intersubjective theory and to the related core concept of mutual recognition. Recognition, as a concept, originally stemmed from philosophy and had different meanings which she transformed when she transferred recognition into relational theory and practice. She refers to her ideas on recognition as "recognition theory" (Benjamin, 2018). Benjamin (2018) defines recognition in two ways: The first, as a psychic stance or position in which we know the other's mind as separate from our own, and second, as a process in which there is an impact of the other's mind or subjectivity on us, and we seek to also have a reciprocal impact upon him or her. She states that "the other must be recognized as another subject in order for the self to fully experience his or her subjectivity in the other's presence" $(1995$, p. 30).

Benjamin (2018) asserts that recognition is a developmental achievement in that we are able to see the other as 
an other, as separate from us, differentiated, that I, a distinct individual, understand you, a separate subject. Our patients thus have a mind of their own, but also, they equally influence our state of being. The implication of recognition is that we need to be known by the other as a separate other. It forms part of our psychological development and the establishment of a sense of self. Recognition of the other links to Winnicott's (1971) seminal idea of the development of the early infantile ego. For him the mother sees her baby and the baby sees himself in the reflection of his mother, and as a result, he has a growing sense of existence, personalization and integration. This is a moment of specificity in recognition that Winnicott called the "sacred moment" - a "moment of meeting" that comprises a new integration in the baby's inner and its outer worlds of awareness. Such moments of recognition lead not only to a sense of self but to what Winnicott (1971) described as the experience of the "true self".

Drawing on the ideas of Aron (2019), empathy and recognition embody distinct values, priorities, feelings, and forms of relatedness and thus responsiveness. They each highlight differing forms of human relationality. Empathy is about understanding another's experience, to grasp the other's experience as fully as possible so that the other has a sense of being understood. Recognition by contrast, not only is about understanding and resonating or attunement to another, but also adds the element of understanding the other as other, as a separate (Aron, 2019).

Empathy is how we show our understanding, our attunement to the other's feeling, but to give it requires differentiation from the other. To receive empathy does not require differentiation. One can receive it and drink it in without giving a thought to who/how it is given (Aron, 2019). Recognition is knowing this other mind understands me, this other mind is reaching out to me. It means that I am causing her to reach out, I am having an effect on her, and this is changing what is going on for me (Aron, 2019).

Empathy is an attempt to fully understand the other's experience, to close the gap between the two subjectivities, whereas recognition includes a distinct awareness of otherness.

\section{The case of Garret}

Garret, ${ }^{1}$ aged 35 years, came to my rooms for help with trying to manage his jealousy. He had been in a relationship with Rose for two years. In the first session, Garret stuck me as a well-dressed, friendly, and introspective man who wanted to make sense of things, especially his jealousy of Rose and her male friends. He explained to me that one evening about four months ago he had c o m e

ho me

to un- ${ }^{1}$ The name Garret and all other names mentioned, are all pseu-

e $\mathrm{X}$-donyms. Furthermore, all identifying data mentioned have been disguised to protect the identity of the client and the client's family. pectedly find Rose chatting in the kitchen with her work colleague, David. This situation made him feel instantly jealous, and it is this jealous experience that brought him to therapy.

In the first session, Garret explained that Rose and David had stayed up late into the night talking without him. Garret thought David would leave for the night soon after dinner as it was already late and a working week, but he did not. Instead, David stayed chatting with Rose long after Garret had retired to bed for the night.

Below is a short extract from the first session.

GARRET: When I came home from work, I suddenly found Rose and David talking in the kitchen, and I felt instantly jealous. I don't know what came over me. I didn't know he would be there but I wanted him to leave the house. He should have left when I came home.

THERAPIST: So, you arrived home to find an unexpected visitor in your kitchen chatting with Rose. It sounds like it could not have been easy for you to see them together. This jealousy you speak about, can you say more about it, can you help me to understand what was happening for you?

GARRET: Sure thing. I remember that I felt this jealousy inside, a kind of feeling of being really insecure. I felt like my world was shaking, as if something bad was going to happen to me. They invited me to join them in the conversation but they also seemed to ignore me. They just carried on talking together long after dinner.

THERAPIST: Seeing them together like that, and feeling this kind of insecurity, gave you a sense of foreboding, like something bad was going to happen. From what I understand about your experience is that for you seeing them together like that, not only did you feel jealous and sidelined, but I wonder if the jealousy was perhaps about feeling that the actual relationship with Rose was, in your mind, being threatened?

GARRET: Yes, I think so. I know they tried to include me but I felt like I was being pushed out. When I saw them together like that I did wonder if she liked him more than me. I remember that I was actually shaking most of the time, trying to control my jealous feelings. I felt that I was losing her to this man. When I think about it, I did once before feel jealous about a male friend she had and I was told by Rose that I was being silly.

THERAPIST: So, I hear that your jealous feelings have been around before, and sharing them with her you got a message that these feelings were unrealistic. That must have been difficult for you that in sharing your feelings you had that response. What I also think I hear, and you can correct me if I am wrong here, in your mind your relationship with Rose had been threatened before. This jealous feeling is not new to you. I can understand how this must be quite unsettling.

GARRET: Yes exactly. And I remember that I felt in that moment I was breaking up inside. She seemed to be enjoying his company far too much. I felt I may lose her. 
THERAPIST: Breaking up inside and being shaky sounds unpleasant. The thought of losing her sounds ... well, I can imagine this must feel, well, terrible, but how would you describe the feeling?

GARRET: Awful. Unsettling.

THERAPIST: It shakes you up.

GARRET: Yes.

THERAPIST: Makes life seem unbearable.

GARRET: Yes exactly. Do you know what this feels like? I want to have Rose think of me as the center of her universe. I want her for myself. When there are these other men in her life, I feel like they are pushing into her life, and pushing me out. Trying to steal her way from me.

THERAPIST: Like what happened with David in the kitchen, in your mind he was trying to take Rose away from you, pushing you out. This threat of losing her is a big thing. To always feel jealousy when there are men around with her can't be easy. To be jealous and insecure, if I have it right, is to feel that she could leave you, and this could be linked to that feeling you spoke about of something bad going to happen.

GARRET: Yes. I felt threatened by David. I have felt threatened by other men when they hang around her. Does this make sense to you? She is so beautiful and I wonder why she hangs out with me. David is so charming and smart and rich. All these things I am not.

THERAPIST: It makes sense to me that you would feel threatened by David. Part of your jealousy of David, if I understand you correctly, is that you find yourself comparing yourself with David, and coming up short, falling below some standard you have of yourself.

GARRET: Yes. I fall way short. He is up there and I am below. I don't measure up.

THERAPIST: You doubt yourself.

GARRET: Yes.

THERAPIST: And doubting yourself is painful.

GARRET: Yes.

THERAPIST: Not measuring up is to have some lack in yourself.

GARRET: Yes.

THERAPIST: Tell me about this sense of doubting yourself, of this pain of doubting, this lack, or lacking something inside, what do you think this is this about?

GARRET: Not sure. What I do know is that something resonated with me when you said my doubting myself is painful. It really is painful. It is painful to feel less and that I lack something. It is painful to feel excluded. It is painful to feel she will leave me. It is painful to not be as smart as David. It is painful to be jealous all the time.

THERAPIST: It is painful to feel jealous and insecure, to feel you may lose her.

GARRET: Yes. It is painful to feel like this.

THERAPIST: That somehow you are not good enough.

GARRET: Yes.

THERAPIST: Can you share a bit more about not feel- ing good enough? I get the sense that it is painful, it makes you feel jealous and insecure, but I wonder if there is something else going on here.

GARRET: I think it is about not feeling good enough for my father.

THERAPIST: So, you felt that your father was maybe disappointed in you, found you to be lacking, not good enough. Have I got this right? Could we explore this a bit? Would that be okay?

GARRET: Okay.

\section{The empathic process: The case of Garret}

Kohut $(1959,1981,1984)$ postulated that patients gradually internalize the (selfobject) analyst's empathy, thus increasing an empathic knowing that shapes the core of their sense of self. He placed empathy at the center of the therapeutic process. In my mind, empathy is a therapeutic way of being together, a living with the patient. What has helped me to conceptualize this process of being with, as shown in the case of Garret, is knowing that the Greek word for empathy is empathein which means indwelling, which describes an imaginative entry and indwelling into the inner life of another. In my session with Garret, I like to think that I was indwelling in his inner world, and that I understood what he felt by feeling and thinking my way into his inner life. For example, my feeling into his experience was expressed in several ways such as, "That must have been difficult for you that in sharing your feelings you had that response", and "The thought of losing her sounds really terrible", and "Makes life seem unbearable".

I also like to think that I conveyed to Garret my understanding of his experience in a way that permitted him to reject, modify, expand and maybe accept my understanding. For example, my response to Garret in some moments were, "From what I understand about your experience", and "What I also think I hear, and you can correct me if I am wrong here", and "If I understand you correctly", permitted him to correct me or clarify. Such responses are based in an empathic process that attempts to understand the other's experience, or, in this case, Garret's experience.

My attempt to remain immersed in his world, and to be a part of an empathic process, is based on how Garret related to me, and I to him. In our session, the empathicbased communication permitted an organic development of his experience of jealousy as this experience progressively transformed into other experiences - for example, from jealousy to insecurity, to something bad was about to happen, to being ignored, to feeling inadequate in the shadow of David, to feeling not good enough for Rose, and finally, perhaps significantly in terms of psychodynamic manifestations of the past, to a sense that he was not good enough for his father.

Garret doubted his self-worth, and this made him feel inadequate. An empathic process permits and permitted the discovery of these other deeper feelings that lay be- 
neath his jealousy. This uncover of deeper feelings links to what I mentioned earlier that empathy is akin to a sacred journey that requires the utmost care, veneration and patience and gives way to the emergence of other feelings that lie dormant and unexpressed - an unformulated experience (Stern, 1997).

Empathy is a reaching out to understand our patient's inner world but it is also an invitation to the patient to search out our subjectivity so that she or he can know if we can manage and survive (Geist, 2013). For example, he asked me at one point in the session, "Do you know what this feels like?" and, "Does this make sense to you?". Garret was exploring my capacity to understand his feelings but also to tolerate his feelings, more specifically, his difficult feelings. This is core to his searching me out and thus, if I am tolerating his difficult feelings, to his healing process. basically, if I am unknown to Garret, he cannot progress further or deeper. He will not trust in me, in us, in the process because the process demands a mutual knowing each other. On the other hand, if I am known, and if I can tolerate what I know, if I can understand his feelings, there is an invitation to delve deeper into his own mind because there is a connection between us that is based on him knowing me and knowing that I know him and knowing that I will survive.

An example of this from the case session is:

GARRET: Yes exactly. Do you know what this feels like? I want to have Rose think of me as the center of her universe. I want her for myself. When there are these other men in her life, I feel like they are pushing into her life, and pushing me out. Trying to steal her way from me.

THERAPIST: Like what happened with David in the kitchen, in your mind he was trying to take Rose away from you, pushing you out. This threat of losing her is a big thing. To always feel jealousy when there are men around with her can't be easy. To be jealous and insecure, if I have it right, is to feel that she could leave you, and this could be linked to that feeling you spoke about of something bad going to happen.

[I am relating to his world of how it is to feel that something special, like Rose, maybe lost or taken away. The jealousy is uncomfortable and he tells me this, so I connect to that as well by saying it cannot be easy].

GARRET: Yes. I felt threatened by David. I have felt threatened by other men when they hang around her. Does this make sense to you? She is so beautiful and I wonder why she hangs out with me. David is so charming and smart and rich. All these things I am not.

[In this section, Garret is beginning to trust in me and how I understand what is happening and how he feels. He asks me if it makes sense and brings me in but he also is searching me out to see if I understand what it feels like to be threatened. He becomes vulnerable as a consequence of admitting this fear of being threatened and it flows into a sense of why would she hang out with him when David is so much better than him. I feel compassion for him in this moment. I place myself in his world and feel into what it must feel like to not have what David has and to be somehow lacking. I think it must hurt, and so I say this to him,]

THERAPIST: It makes sense to me that you would feel threatened by David. Part of your jealousy of David, if I understand you correctly, is that you find yourself comparing yourself with David, and coming up short, falling below some standard you have of yourself. This must hurt.

GARRET: Yes. It hurts. I fall way short. He is up there and I am below. I don't measure up.

[Here Garret realizes that it is painful and it hurts to not be as good as David. I feel my compassion grow when I hear his words about not measuring up and being below. This is surely, for me, an experience of self-doubt. I reflect back this to him, still feeling into his world].

THERAPIST: You doubt yourself.

\section{Self-reflection on the process thus far}

As the process progresses, Garret opens up more about his feelings because he knows that I am trying to understand him, and in my mind, I believe he feels deeply understood by me. The second part of what this paper is about is making the case for how empathy is core to the development of the experience of holding and recognition. I suggest that holding and recognition are two ways of relating to our patients just as empathy is a way of relating. But empathy grounds and sets the scene for the appearance of holding and recognition. As such, holding and recognition take place within an empathic process, emerging from the experience of being deeply understood. Another way of saying this is to assert that Garret's experience of holding and recognition cannot happen without an experience of empathy. If patients like Garret don't feel deeply understood, holding and recognition will not occur because these kinds of relating emerge first from this feeling of being deeply understood.

Holding emerged after the experience of empathy. If we look again at the dialogue, holding took place a little later into the session. For example,

\section{Continuation of analysis}

THERAPIST: You doubt yourself.

GARRET: Yes.

THERAPIST: And doubting yourself is painful.

GARRET: Yes.

[At this point the empathic process is on-going, and Garret begins to feel the pain of doubting himself. As we carry on working together, something else begins to happen - an experience of holding. This is not found earlier in the dialogue].

THERAPIST: Not measuring up is to have some lack in yourself.

GARRET: Yes. 
THERAPIST: Tell me about this sense of doubting yourself, of this pain of doubting, this lack, or lacking something inside, what do you think this is this about?

GARRET: Not sure. What I do know is that something resonated with me when you said my doubting myself is painful. It really is painful. It is painful to feel less and that I lack something. It is painful to feel excluded. It is painful to feel she will leave me. It is painful to not be as smart as David. It is painful to be jealous all the time.

THERAPIST: It is painful to feel jealous and insecure, to feel you may lose her.

GARRET: Yes. It is painful to feel like this.

THERAPIST: That somehow you are not good enough.

[This exchange shows the experience of holding becomes more differentiated and it allows me to speak what is perhaps unspoken - that he is not good enough. At this stage, he does not have to know me, as holding means that he can be immersed in his experience without being mindful of the other. I have bracketed my subjectivity and it is no longer about me but about his capacity to soften into the holding frame and become vulnerable to the pain of not being good enough. His reply affirms this].

GARRET: Yes.

[Holding is closely related to recognition but it is not the same (Slochower $(2011 ; 2014)$. Holding does not require Garret to know me in that moment except perhaps that I will survive but my subjectivity is not introduced nor do I ignore it. Recognition emerges from this holding. It is possible that it can emerge before holding but it emerges because of the on-going empathic process. there are moments of recognition in the session, some occur just before this transcript above, and others afterwards but they occur later on once Garret knows that I understand him.

Based on what recognition has been defined, here is an example from our session of recognition]

THERAPIST: Can you share a bit more about not feeling good enough? I get the sense that it is painful, it makes you feel jealous and insecure, but I wonder if there is something else going on here.

[In order to ask this question Garret would have needed to have felt deeply understood by me. I have a sense that he is on the edge of discovery and opening up a new level of introspection and experience. We have been together to this point, or what I like to say as living with and being with so that he can know my mind as separate and his mind as impacting on my mind and vice versa. We are two minds connection so that he can go deeper into his world. His reply is a sense of recognition of my mind and of his own in relation to me].

GARRET: I think it is about not feeling good enough for my father.

THERAPIST: So, you felt that you father was maybe disappointed in you, found you to be lacking, not good enough. Have I got this right? Could we explore this a bit? Would that be okay?

GARRET: Okay.
Another example, in a previous section of the session that illustrates recognition is as follows.

THERAPIST: Makes life seem unbearable.

GARRET: Yes exactly. Do you know what this feels like?

[In this dialogue Garret is actively bringing my mind into his process and he can only do this if he sees me as a separate mind].

\section{Conclusions}

I have presented a short exert of a session with my patient, Garret, to show what empathy and the empathic process looks like in the clinical setting. I showed that it is first an experience of empathy in the intersubjective space that facilitated the unfolding of a safe space or holding experience. My bracketing, as therapeutic action, and his folding into that bracketing, is about two people doing something so that holding is co-created. In other words, it is not just something I do (bracketing), but it is also something he does (folds into the bracketing) - he can be without engaging with me, so that his experience can exist without my impingement. It is noted that with Garret holding is not an experience of a trajectory forward but it can be circular or returned to later if needed. In this regard, empathy facilitated the experience of holding because without first been deeply understood, Garret could not experience holding.

Empathy also facilitated the experience of recognition. Without empathy or without Garret feeling deeply understood, he could not experience me as a separate subjectivity. At times he asked about my experience which is evidence that he experienced my separateness. This questioning of my experience was only after his experience of being deeply understood.

The relationship between the experiences of holding and recognition are close but not the same. There may be experiences of holding but not of recognition, and the same can be said of the opposite - there maybe experiences of recognition but not of holding. Both are different experiences and are not dependent on each other. In relation to empathy, holding moves us together, connects us, but not connection as a merger or joining where there is no differentiation or boundaries. Recognition remains about two minds relating to each other as two separate minds, but recognition means that while the other is deeply known, the other remains separate.

Finally, I want to also mention something less spoken about. While empathy is to enter into the world of our patients, to be deeply known, empathy can be experienced as unsetting. Any attempt to be known can be, in some cases, met with psychic balustrades that feel like hitting a brick wall, and thus for us an experience of being warded off. In being deeply understood, empathy may be disruptive or terrifying and destabilizing. In this case, the empathic process may take a little longer to emerge. If this 
is the case, holding and recognition, as experiences of being and relating, may also be somewhat delayed.

\section{References}

Aron, L. (1991). The patient's experience of the analyst's subjectivity. Psychoanalytic Dialogue, 1, 29-51.

Aron, L. (1992). Interpretation as expression of the analyst's subjectivity. Psychoanalytic Dialogue, 2, 475-508.

Aron, L. (1996). A meeting of minds. Hillsdale, NJ: The Analytic Press.

Aron, L. (2019). Discussion of "Bread and Roses: Empathy and recognition". Psychoanalytic Dialogue, 29,1, 92-102. doi: 10.1080/10481885.2018.1560864

Atlas, G., \& Aron, L. (2018). Dramatic dialogue: Contemporary clinical practice. New York, NY: Routledge.

Bacal, H. A. (1990). The elements of a corrective selfobject experience. Psychoanalytic Inquiry, 10, 347-372.

Balint, M. (1968). The basic fault. London, UK: Tavistock.

Bassin, D., M. Honey, \& M. M. Kaplan (Eds). (1994). Representations of Motherhood. New Haven, CT: Yale University Press.

Benjamin, J. (1995). Like subjects, love objects. New Haven. Yale University Press.

Benjamin, J. (1988). The bonds of love: Psychoanalysis, feminism and the problem of domination. New York, NY: Pantheon.

Benjamin, J. (2018). Beyond doer and done to: Recognition theory, intersubjectivity and the third. New York, NY: Routledge.

Bion, W. (1962). A theory of thinking. International Journal of Psycho-Analysis, 43, 306-310.

Bollas, C. (1978). The transformational object. International Journal of Psycho-Analysis, 60, 97-107.

Burke, W. F. (1992). Countertransference disclosure and the asymmetry / mutuality dilemma. Psychoanalytic Dialogue, 2, 241-271.

Chodorow, N. (1978). The reproduction of mothering. Berkeley, CA: University of California Press.

Fosshage, J. (1997). Listening/experiencing perspectives and the quest for a facilitating responsiveness. In A. I. Goldberg, (Ed.). Progress in self psychology: Conversations in self psychology, (pp. 33-55). Hillsdale, NJ: Analytic Press.

Geist, R. A. (2007), Who are you, who am I, and where are we going: Sustained empathic immersion in the opening phase of psychoanalytic treatment. International Journal of Psychoanalytic Self Psychology, 2, 1-26.

Geist, R. A. (2010), Connectedness, permeable boundaries, and the development of the self: Therapeutic implications. International Journal of Psychoanalytic Self Psychology, 3, 29-152.

Geist, R. A. (2013). How the empathic process heals: A microprocess perspective. International Journal of Psychoanalytic Self Psychology, 8,3, 265-281. doi: 10.1080/15551024. 2013.800357

Grant, D and Harari, E. (2011). Empathy in psychoanalytic the- ory and practice. Psychoanalytic Inquiry, 31, 3 - 16. doi: 10.1080/07351690.2010.512844

Hoffman, I. Z. (1991). Discussion: Toward a social-constructivist view of the psychoanalytic situation. Psychoanalytic Dialogue, 1, 74-105.

Kohut, H. (1959). Introspection, empathy, and psychoanalysis. Journal of American Psychoanalysis Association, 7, 459483.

Kohut, H. (1981). On empathy. In P. H. Ornstein, (Ed.). (1978). The Search for the Self: Selected Writings of Heinz Kohut, 1978-1981, Vol. 4, (pp. 525-536). Madison, CT: International Universities Press.

Kohut, H. (1984). How does analysis cure? Chicago: University of Chicago Press.

Loewald, H. (1960). On the therapeutic action of psycho-analysis. The International Journal of Psychoanalysis, 41,16-33.

Mitchell, S. A. (2000). Relationality: From attachment to intersubjectivity. Hillsdale, NJ: Analytic Press.

Ornstein, P. (2011). The centrality of empathy in psychoanalysis. Psychoanalytic Inquiry, 31, 437-447.

Pillsbury, S. (2019). Mutual Empathy: Imagined symbol and realization in the treatment of trauma. Psychoanalysis, Self and Context. 14(3), 247-255. doi: 10.1080/24720038. 2019.1602135

Slochower, J. (1996). Holding and psychoanalysis: A relational perspective. Hillsdale, NJ: The Analytic Press.

Slochower, J. (2006). Psychoanalytic Collisions. Hillsdale, NJ: The Analytic Press.

Slochower, J. (2011). Holding, collaborating, colliding: A cross theoretical conversation. Psychoanalytic Inquiry, 31, 501512 .

Slochower, J. (2014). Holding and psychoanalysis: A relational perspective, second edition. London, UK: Routledge.

Slavin, M. \& Kriegman, D. (1998/2009). Why the analyst needs to change: Toward a theory of conflict, negotiation, and mutual influence in the therapeutic process. In L. Aron \& A. Harris, (Eds.).

Relational Psychoanalysis; Volume II: Innovation and Expansion. New York, NY: Routledge.

Stern, D. (1997). Unformulated experience: From dissociation to imagination in psychoanalysis. Hillsdale, N.J: The Analytic Press.

Stern, D. (1992). Commentary on constructivism in clinical psychoanalysis. Psychoanalytic Dialogue, 3, 331-364.

Stolorow, R., Atwood, G. \& Orange, D. (2002). Worlds of experience. New York, NY: Basic Books.

Tansey, M. J. (1992). Psychoanalytic expertise. Psychoanalytic Dialogue, 2, 305-316.

Winnicott, D. W. (1955). Metapsychological and clinical aspects of regression within the psychoanalytic relationship. The International Journal of Psychoanalysis, 36, 16-26.

Winnicott, D. W. (1960). The theory of the parent-infant relationship. In D. Winnicott, (1965). The maturational processes and the facilitating environment, (pp. 37-55). New York, NY: International Universities Press.

Winnicott, D. W. (1971). Playing and reality. New York, NY: Basic Books. 